\title{
Ideological and Conceptual Content of the US Approach to Structuring the Indo-Pacific Macroregion
}

\author{
Ivan R. Dubrovskiy ${ }^{1, *}$ Chan Duy Thanh ${ }^{1, a}$ \\ ${ }^{1}$ Department of Theory and History of International Relations, RUDN University, Moscow, Russia \\ ${ }^{a}$ Email: myhoney292@gmail.com \\ *Corresponding author. Email: 1032171352@rudn.ru
}

\begin{abstract}
The article is devoted to the ideological content of the American approach to the restructuring of the Indo-Pacific region. Currently, the interconnectedness of the problems of international regional relations in Asia, as well as the strategic competition between the United States and China for leadership in this region, have led to the formation of the Indo-Pacific macroregion. The authors focus on the constructivist interpretation of macroregional transformations, which increases the importance of studying the ideological and conceptual background of the policy of the state claiming leadership. The article analyzes the main concepts of the US administration since the 2010s. The focus is on the "rules-based order" doctrine, which sets the tone for America's «Free and Open Indo-Pacific» strategy. The authors come to the conclusion that the ideological and conceptual content of the American strategy has not undergone significant changes over the past decade.
\end{abstract}

Keywords: Indo-Pacific macroregion, USA, China, Strategic competition, "Rules-based order", Social Constructivism.

\section{INTRODUCTION}

The multi-format and interconnectedness of the problems of international regional relations in the new geopolitical and geo-economic conditions allows us to analyze the trends in the political development of regions together with the "connected" territories and in connection with a new, more complex and refined system of geoeconomic, axiological and other factors. Such a new form of interconnection enlarges regional divisions and forces us to rethink the role of macroregions in world politics.

Obviously, any region is a socially constructed concept, and often politically and value-challenged. So, in the context of the increasing penetration of great and regional powers into adjacent regions, there is an increase in the interdependence of a particular region (mainly through the policies of great and regional powers) with "adjacent" territories. This leads to the formation of macroregions consisting of two or more regions and sub-regions, which is evident from the strengthening of relationships in different regions in the post-bipolar period.

An example of such a "connected" of regions is the now updated concept of the "Indo-Pacific region". The formation of this macro-regional complex was stimulated not only by geographical, political and security factors, but also by ideological, axiological and conceptual processes. These processes cover the "contiguous" territories of North-East, South-East and South Asia.

In the proposed study, the author relies on the constructivist interpretation of the regional complex by $\mathrm{A}$. Wendt, in which, in addition to traditional material factors, the ideological processes become important, because these processes can be considered as originally inherent in the region, and not introduced from the level of the international system [1]. At the same time, the effectiveness of constructivist mechanisms is ensured by the complex power of the player interested in asserting its leadership among the critical mass of states. This admission leads to an appeal to the neorealist 
"power transition theory", which was first used for the analysis of regional processes in the work of $\mathrm{D}$. Lemke [2].

Faced with strategic competition with China in Asia, the United States is taking a set of measures aimed at preventing changes in the order in the Indo-Pacific macroregion. The aim of this study is to define the American ideological and conceptual approach to the formation of Indo-Pacific.

\section{CONCEPTUAL BACKGROUND OF THE US APPROACH TO CHANGING THE MACRO- REGIONAL ORDER IN THE INDO- PACIFIC}

In the early 2010s, the United States followed an approach to the international and regional order that was based on the idea of "post-American exceptionalism". In accordance with this idea, American global and regional leadership should be reformatted and aimed not at domination, but at international cooperation, which is reflected in such ideas as "burden-sharing" and "leading from behind". "Post-American exceptionalism" was supposed to help the United States get closer to its allies and reduce the need to intervene in conflicts in the international arena through military and political means [3].

The concept of "leadership from behind" also demonstrated the continued evolution of the idea of "American exceptionalism" in foreign policy, because it was planned to make a transition from unilateral actions of the military-political hegemon to collective actions under the leadership of the strongest ally [4].

The change in the understanding of "American exceptionalism" in the neoliberal vision of Barack Obama was enshrined in the National Security Strategy of 2010 [5]. This approach led to a dual policy in East Asia, where the United States attempted to rebrand the type of relations that had developed since 1972, while at the same time trying to keep the Southeast Asian countries in its zone of influence (the "congagement" policy).

With the coming to power of President Donald Trump and the proclamation of the strategy "Free and Open Indo-Pacific" (FOIP), the ideological and theoretical foundations of US foreign policy have acquired a new perspective. In the macroregion, the US Indo-Pacific has begun testing its own "rulesbased order" doctrine [6], where "rules" can be qualified in accordance with certain common values shared by regional states.

Initially, they focused mainly on economic cooperation between the United States and the states of the region, primarily China. President Trump in Da Nang Summit of APEC (2017) stressed the need to establish "fair", "mutual" trade relations based on such principles as respect for intellectual property rights, free trade and protection of private property, fair competition and open markets [7]. Respect for these principles, D. Trump called "playing by the rules".

\section{DOCTRINE OF "RULES-BASED ORDER" AS THE BASIS OF THE US IDEOLOGICAL AND CONCEPTUAL APPROACH}

Due to the lack of a single concept document, it seems appropriate to refer to the analytical note of the Australian Institute of Asia at Griffith University. I. Hall and M. Heazle, where the researchers made a discursive analysis of the political rhetoric of the United States, Japan and Australia. The doctrine of "order based on rules" was divided by the functional parts that are perceived as the most vulnerable to the United States and its allies in the Indo-Pacific industry. In terms of economic order, the "rules" should reinforce an open economy, freer trade and investment. In the field of security, the need to move away from the customary law of the sea in favor of the 1982 UN Convention on the Law of the Sea is emphasized, especially in matters of Exclusive economic zone compliance, maritime boundary demarcation, and seabed rights. The principles of respect for the sovereignty and independence of all States and the peaceful resolution of conflicts are emphasized. Much attention is also paid to the issue of human rights. The new order should be based on individual rights and some basic liberal values (democratic governance, individual freedom, rule of law, market economy, etc.) [8].

This doctrine is characterized by alarmism. It implicitly contains a view of China (as one of the illiberal and authoritarian countries) as a revisionist power that has provoked by its actions the erosion of the norms of the international order. This is shown by the analysis of the categories "free" and "open", which are attributed to the Indo-Pacific. "Free" means the freedom of all States to exercise their sovereignty without interference from other States. At the national level, this is consistent with 
good governance and the protection of human and civil rights. "Open" is interpreted as free access to international waters, airspace and digital space, as well as open access to markets and fair mutual trade. From the US point of view, China is also increasingly underestimating the principle of openness, in particular by militarizing artificial islands in the South China Sea [9].

The US concept papers emphasize the importance of investment for the region, especially in infrastructure, and call for a stronger role for the United States in infrastructure investment as an alternative to "state-owned" (i.e., Chinese) investment [10]. Thus, these documents leave little doubt that the FOIP is primarily a reaction to China's behavior, which, according to the Americans, is becoming increasingly "aggressive" and "undermines" the rules - based international order. In particular, the document of the Ministry of Security more clearly portrays China as a "revisionist power" than the creative goals and strategy of the United States in Indo-Pacific [11].

Russian academic D. Mosyakov interprets this phenomenon as a reactualization of the political mythology and propaganda experience of the Cold War era: the struggle of free countries against the totalitarian and aggressive "force of evil" [12]. "Through fear and coercion, Beijing is working to expand its form of ideology to bend, break, and replace the existing rules-based international order. Instead, the Chinese authorities seek to create a new order based on Chinese approaches, and this undermines the stability and peace in the IndoPacific region, which has existed for more than 70 years" [13].

This doctrine also has a characteristic of onesidedness. The elites of the United States and its allies do not take into account that China's "rulesbased" approach is no less than their own vision, since it is based on the principles of the UN Charter, and does not exclude many current forms of international cooperation, including extensive trade, investment, and cooperation on vital transnational issues such as climate change. China is also a consistent advocate of multilateralism at all levels of the world system: regional (the Good-neighbor policy), trans-regional («Belt and Road Initiative»), and global («Community of common destiny» concept).

On human rights issues, China prefers a more Westphalian concept of order, where State sovereignty and non-interference are of paramount importance, and respect for individual rights is viewed through the prism of "the rule of law in internal affairs". Nevertheless, a world dominated by China's preferences will be different from a world in which the American vision has proved more influential. This, from the author's point of view, is the reason for the new doctrine, which serves as the background of modern US policy in the macroregion of the Indo-Pacific. Unsurprisingly, the mission of building a "rules-based order" has been entrusted to the Quadrilateral Security Format (Quad) and bilateral alliances.

The ideological and theoretical approach of the United States to IT is based on the symbiosis of Realpolitik and liberalism. The only way the United States can hope to protect and advance its interests in IT in the next decade is to become part of a coalition of countries with common goals and values. The region's democracies are recognized as natural allies of the United States. Based on these postulates, the US strategy in the IT sector acquires an accentuated pro-democratic character. Its key vectors were summarized in a report by the National Bureau of Asian Studies. In particular, the strategy aims to strengthen relations with the democracies of the region and to make these democracies stronger and more secure. The latter involves promoting their economic growth, strengthening their defense capabilities, and helping to end internal conflicts that are sapping their strength. It also entails strengthening democratic institutions within these countries, reducing external threats to them, and increasing the ability of the United States to come to their defense if necessary.

Moreover, it is assumed that as part of strengthening democracy, the United States will respond to natural disasters, humanitarian crises and economic crises. At the same time, the US strategy does not ignore other countries in the region. In particular, it aims to promote democratization and human rights in countries that are not yet democratic [14]. Apparently, this is how the Trump administration explained the selective approach to determining the points of support in the region, which was manifested in the allocation of Vietnam as a key partner.

The importance of the liberal-democratic component in the FOIP strategy is indicated by the fact that the Law "On the Asian Reassurance Initiative Act" (ARIA) was supposed to allocate \$ 1.5 billion annually for the needs of state departments. Of this, \$ 236 million was allocated 
to issues related to supporting democracy in regional countries [15].

\section{CONCLUSION}

Thus, it should be stated that the ideological and conceptual content of US foreign policy in the macroregion is based on the fundamental paradigms of American policy and is the fruit of the adaptation of the US establishment to the destabilization of the world order. Functionally, the strategy of President Trump continues the strategy of B. Obama, exercising "leadership from behind".

It is obvious that at the present stage of the development of the system of international relations, one of the characteristic features and features of the ideological and theoretical apparatus of the United States in relation to foreign policy issues is rationalism, which can be seen in the instrumental nature of relations with the SRV or in the revival of the political mythology of the Cold War.

\section{AUTHORS' CONTRIBUTIONS}

Chan Duy Thanh conceived of the presented idea and designed the theoretical framework. Ivan Dubrovskiy contributed to the design and implementation of the research, to the analysis of the results and to the writing of the manuscript.

\section{REFERENCES}

[1] Wendt, A. Social Theory of International Politics. Cambridge: Cambridge University Press, 1999. 264 p.

[2] Lemke D. Regions of War and Peace. Cambridge: Cambridge University Press. 2002. $235 \mathrm{p}$.

[3] Loefflmann G. Leading from Behind American Exceptionalism and President Obama's Post-American Vision of Hegemony // Geopolitics. 2015. Vol. 20, Iss. 2. P. 308332.

[4] Hrnjaz M., Krstic M. Obama's Dual Discourse on American Exceptionalism // CIRP. 2015. No. 73. P. 25-56.

[5] National Security Strategy of the United States // The White House. 2010. URL: https://obamawhitehouse.archives.gov/sites/de fault/files/rss_viewer/national_security_strateg y.pdf
[6] Australia's Security and the Rules-Based Order. Tracking a Decade of Policy Evolution // Lowy Institute. URL: https://interactives.lowyinstitute.org/features/r ules-based-order/

[7] Remarks by President Trump at APEC CEO Summit // US Mission to ASEAN. 10 November 2017.2 URL: https://asean.usmission.gov/remarkspresident-trump-apec-ceo-summit-da-nangvietnam/

[8] Hall I., Heazle M. The Rules-Based Order in the Indo-Pacific // Griffith Asia Institute. 2017. No. $50 . \quad$ URL: https://www.griffith.edu.au/_data/assets/pdf_ file/0023/108716/Regional-Outlook-Paper-50Hall-Heazle-web.pdf

[9] Secretary of Defense Mark T. Esper Remarks at Diplomatic Academy of Vietnam / U.S. Embassy and Consulate in Vietnam. 20 November 2019. URL: https://vn.usembassy.gov/secretary-ofdefense-mark-t-esper-remarks-at-diplomaticacademy-of-vietnam/

[10] National Security Strategy of the United States of America. December 2017. URL: https://www.whitehouse.gov/wpcontent/uploads/2017/12/NSS-Final-12-182017-0905-2.pdf; Free and Open Indo-Pacific: Advancing a Shared Vision, 4.11.2019. URL: https://www.state.gov/wpcontent/uploads/2019/11/Free-and-Open-IndoPacific-4Nov2019.pdf

[11] Indo-Pacific Strategy Report. Preparedness, partnerships, and promoting a networked region / US Department of Defense, 1 June 2019.

URL: https://media.defense.gov/2019/Jul/01/200215 2311/-1/-1/1/DEPARTMENT-OF-DEFENSEINDO-PACIFIC-STRATEGY-REPORT2019.PDF

[12] Mosyakov, D.V. Global Transformation of Pacific Asia and Russia. Moscow: Belyi veter publ. 2019. 390 p.

[13] Indo-Pacific Command Worried About China's Path / DOD News. Feb. 12, 2019. URL: https://www.defense.gov/Explore/News/Articl e/Article/1755357/indo-pacific-command- 
worried-about-chinas-path/ (date of access: 22.02.2021).

[14] NBR Special Report № 86 «A New U.S. Strategy for the Indo-Pacific» // The National Bureau of Asian Research. June 2020. 121 p.

[15] Asia Reassurance Initiative Act. S.2736 / 115th Congress. 31.12.2018. URL: https://www.congress.gov/bill/115thcongress/senate-bill/2736/text 